Vol. 6, Issue 6, June 2019

\title{
The Effect of Transformational Leadership on Innovation in Syrian Universities
}

\author{
Baraa Alnesr ${ }^{1}$, Dr. Sara Ravan Ramzani ${ }^{2}$ \\ Ph.D. (Management), Limkokwing University of Creative Technology, Cyberjaya, Malaysia ${ }^{1}$ \\ Lecturer, Limkokwing University of Creative Technology, Cyberjaya, Malaysia ${ }^{2}$
}

\begin{abstract}
Previous studies have pointed out that transformational leadership is an important factor affecting innovation in an organization. However, there is a lack of models linking transformational leadership and innovation at universities within developing countries, particularly Syria. The purpose of this study was to examine the effect of transformational leadership on innovation in Syrian universities. The quantitative method was used in data collection. A stratified random sampling technique was conducted which comprised of 368 valid responses to test the causal relationship between transformational leadership and innovation. PLS-SEM technique was used to analyze the relationship between the variables in this study. The results show that there was a significant relationship between transformational leadership and innovation.
\end{abstract}

Keywords: Transformational leadership, Innovation, Syrian universities

\section{INTRODUCTION}

Obendhain and Johnson (2004) pointed out that Higher Education Institutions (HEIs) are important as they are producers of innovation, as a result of creating products and services. The higher education sector today is facing global challenges from the rapid technological change and increased demands of today's world (Mathew, 2010).

As innovation becomes critical to the survival of organizations and a key factor in achieving competitive advantage, leadership style has been identified as an important factor affecting innovation because leaders can influence the introduction of ideas, set specific goals and create a culture for innovation (Sarrors et al. 2008). According to Phong et al (2018) in a study in Vietnamese firms, the result shows that transformational leadership has significant effect on innovation. However, a causal link amongst two factors has not been developed to date in Syrian universities. Therefore, this study seeks to examine the effect of transformational leadership on innovation in Syrian universities.

\section{LITERATURE REVIEW}

\section{Transformational Leadership}

According to Yukl (2010), there is no general agreement on the definition of leadership. Almost all writers who tried to define leadership have their own definitions and there is no commonly agreed upon definition. According to Yukl (2010), there is no general agreement on the definition of leadership but most definitions cover these concepts: leadership is a "process" by which a leader can affect and be affected by their subordinates. The leader's "influence" on the followers, is considered a necessary condition without which leadership cannot exist. Leadership occurs in a "group" and influences the individuals in that group to have the same goals as the leader. It involves the "accomplishment" of set of goals through the direction of a group of people.

Leadership plays a vital role in establishing high-performing teams and is one of the critical elements in enhancing organisational performance (Northouse, 2007, Betroci, 2009, DuBrin, 2012). It has been identified as one of the key factors in promoting innovation (Jung et al., 2003). Within the higher education environment, transformational leadership is essential for developing education (Butcher et al., 2000, Green, 2010). Transformational leadership has been found to encourage staff to participate in educational programmes that develop their skills so that they achieve higher performance (Bass and Riggio, 2006). It is argued that, within academic environments, transformational leadership can lead to changes in the strategies and structures similar to those seen in business organisations ( $\mathrm{Yu}$ and Jantzi, 2002).

\section{Innovation}

Herkema (2003) and Demircioglu (2016) both defined innovation as the adoption of new ideas, behaviours, products, systems, processes, policies, and programmes that are new to an organisation. Du Plessis (2007) stated that innovation 


\section{International Advanced Research Journal in Science, Engineering and Technology}

Vol. 6, Issue 6, June 2019

refers to the creation of new thoughts, knowledge and ideas so as to make organisational outcomes possible. Additionally, Vaccaro et al. (2012) explained innovation as a product, process, or distribution method perceived as new by the organisation.

It is argued that innovative behaviour is essential if organisations are to adapt and respond to rapid and unstable environmental and technological changes and survive in the present environment (Kellermanns et al., 2008, Cooper and Edgett, 2009, Trott, 2008). There is a general agreement among scholars that innovation is power for organisations all nowadays (Kamasak and Bulutlar, 2010). Innovation is the most important element underlying an organisation's longterm competitive advantage (de Jong and Hartog, 2007). Lagrosen (2005) noted that innovation can provide entry to new markets and enhance the effectiveness of organisations. It is a primary source of economic growth, providing organisations with opportunities to grow faster and gain profits (Tidd et al., 2005, Trott, 2008, Tidd and Bessant, 2011). Calantone et al. (2002) and Jimenez and Vall (2011) both indicated that innovation is related to organisational learning, makes organisations aware of the latest developments, and helps them to absorb new and related knowledge. Therefore, organisations that have the capacity to be innovative will be able to respond to challenges and exploit new product and market opportunities more quickly than non-innovative organisations (Schilling, 2010).

In higher education environments, innovation is important and it has been said that universities should rely on product and process innovation (Jaskyte, 2004). Rogers (1995-2010) asserted that educational institutions were a way to adopt and apply innovation. Educational quality is reliant on both product and process being adaptive to the changing environment.

\section{THE RELATIONSHIP BETWEEN THE VARIABLES AND HYPOTHESIS DEVELOPMENT}

Transformational leaders are able to build trust and respect among employees, and express confidence in the organisational vision, (Betroci, 2009, Yukl, 2010). Transformational leaders can encourage followers to act on an organization's vision in order to foster innovation (Chen et al., 2012, Si and Wei, 2012). Such leaders have an interactive vision and the capability to encourage an appropriate environment for innovation (Saenz, 2011, Vaccaro et al., 2012). These characteristics encourage members to work hard and be more innovative. Followers under transformational leadership style are not afraid of being criticised if they express a different opinion to their leaders (DuBrin, 2012). When individuals are encouraged to re-think, and know that their ideas are considered important by their leaders, they are more likely to come up with innovative ideas that could enhance innovation (Shalley and Gilson, 2004, Jung et al., 2008). Transformational leaders listen to and care about their followers' ambitions, and contributions, and show them how they can reach their goals (Saenz, 2011). This style of leadership can increase the desires of members of an organisation to take on more responsibility. When leaders are concerned with their followers' personal feelings, and offer support and encouragement, the followers will be more likely to respond with innovation (Al-omari and Hung, 2012, Khan et al., 2009, Gumusluoglu and Ilsev, 2009). From the description above, the researcher proposed the following hypothesis:

H1: Transformational leadership will positively influence innovation in Syrian universities.

From the description above, we can describe the research model as follows:

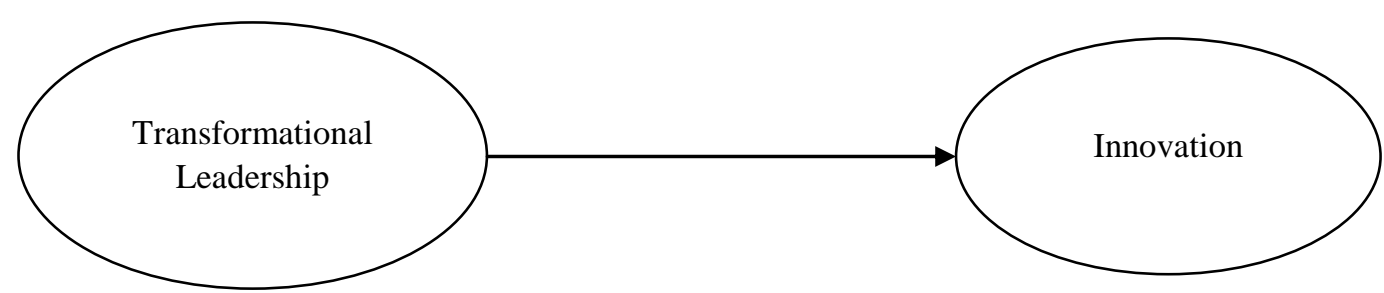

Figure 1. Framework

\section{RESEARCH METHODOLOGY}

Research Design: This study uses the quantitative method approach. Thus, this study is carried out based on positivist principles with a deductive approach in order to examine the causal relationship among transformational leadership and innovation in Syrian universities. This study used a self-administered questionnaire, with closed-ended questions, to collect data from members of staff in universities in Syria. The survey questionnaire was designed to be easy and quick for participants to complete. The design of the questionnaire includes five parts besides the introduction. 


\title{
International Advanced Research Journal in Science, Engineering and Technology
}

\author{
Vol. 6, Issue 6, June 2019
}

Population: The target population in this study comprises academic teaching staff at list of universities in Syria (assistant lecturers, lecturers, assistant professors, and professors). Ten universities were selected from 30 universities in total as the sampling frame.

Sampling design: This study uses the questionnaire approach to gather data, and since the study is focusing in a specific group "Academic staff", contained in different categories (private universities, public universities, and international universities); therefore, stratified random sampling is most appropriate. Since this study is using SEM, the literature suggests that a minimum sample of 200 is required in order to get a statistically significant result and a better performance analysis. Taking this rule into consideration the sample of 368 obtained for this study is therefore sufficient.

\section{RESULTS AND DISCUSSION}

The results of this study show that transformational leadership affects innovation with $\mathrm{R} 2=0.542$, Path Coefficient $\beta=$ 0.415 , and $\mathrm{Q} 2=0.378$.

In this study, the hypothesis tested and based on the results of test. The results showed that the hypothesis is supported by the data.

Table 1. The Hypothesis Test of Research Model

\begin{tabular}{|c|l|c|c|}
\hline Hypothesis & \multicolumn{1}{|c|}{ Hypothesis Statement } & T-Value & Result \\
\hline H1 & $\begin{array}{l}\text { Transformational leadership will positively } \\
\text { influence innovation in Syrian universities. }\end{array}$ & 3.745 & Supported \\
\hline
\end{tabular}

The result of testing the hypothesis found that:

Hypothesis 1: The hypothesis was supported and accepted. The results showed that transformational leadership has a positive effect on innovation in Syrian universities.

\section{CONCLUSION}

The objective of this study was to examine the impact of transformational leadership on innovation in Syrian universities. The specific problem addressed by this study was the lack of models developed to investigate the links between transformational leadership and innovation within universities in developing countries, particularly Syria. The study found that transformational leadership would be ideal in an educational context as it would influence innovation. Meaning that TL promotes and encourages innovation in universities in Syria.

\section{REFERENCES}

[1]. AL-OMARI, M. \& HUNG, K. 2012. Transformational leadership and organisational innovation: The moderating effect of emotional intelligence. International Business Management Vol. 6, No. 3, pp.308-316.

[2]. BASS, B. \& RIGGIO, R. 2006. Transformational leadership, 2nd ed., US, Lawrence Erlbaum Associates, Inc.

[3]. BETROCI, D. 2009. Leadership in organizations- There is a difference between leaders and managers., US, University Press of America.

[4]. BUTCHER, J., MOON, B. \& BIRD, E. 2000. Leading professional development in education, London, Routledge Falmer.

[5]. Calantone, R. J., Cavusgil, S. T., \& Zhao, Y. 2002. Learning orientation, firm innovation capability and firm performance. Industrial Marketing Management, 31(6), 515-524.

[6]. CHEN, C., HUANG, J. \& HSIAO, Y. 2010a. Knowledge Management and innovativeness: The role of organizational climate and structure International Research Journal of Manpower, Vol.31, No.8, pp.848-870.

[7]. COOPER, R. G. \& EDGETT, S. 2009. Product innovation and technology strategy, USA, Product Development Institute Inc.

[8]. De Jong, J. \& Hartog, D. 2007. How leaders influence employees innovation behaviour European Journal of Innovation Management Vol. 10, No. 1 , pp. $41-64$.

[9]. Demircioglu, M. A. 2016. Organizational Innovation. Global Encyclopedia of Public Administration, Public Policy, and Governance, 1-5.

[10]. DU PLESSIS, M. 2007. The role of knowledge management in innovation Journal of Knowledge Management, Vol.11, No.4, pp.20 - 29.

[11]. DUBRIN, A. 2012. Leadership: Reasearch findings, practice, and skills, 7th ed. , New York, Houghton Mifflin company

[12]. GREEN, H. 2010. Transformational leadership in education: stengths-based approach to change for administrators, teachers and guidance conselors, USA, Global Ed Advance Press.

[13]. GUMUSLUOGLU, L. \& ILSEV, A. 2009. Transformational leadership, creativity, and organizational innovation Journal of Business Research Vol. 62, No.4, pp.461-473.

[14]. HERKEMA, S. 2003. A complex adaptive perspective on learning within innovation projects. The Learning Organization, Vol.10, No. 6, pp. 340-346

[15]. JASKYTE, K. 2004. Organizational culture and innovation in nonprofit organizations.

[16]. JUNG, D., CHOW, C. \& WU, A. 2003. The role of transformational leadership in enhancing organizational innovation : Hypotheses and some preliminary findings The Leadership Quarterly Vol. 14, pp. 525 - 544.

[17]. JUNG, D., WU, A. \& CHOW, C. 2008. Towards understanding the direct and indirect effects of CEOS' transformational leadership on firm innovation. The Leadership Quarterly, Vol.19, pp.582-594.

[18]. Kamasak, R. \& Bulutlar, F. S. 2010. Influence of knowledge sharing on innovation European Business Review, Vol. 22 , No. 3 , pp.306 - 317. 


\section{International Advanced Research Journal in Science, Engineering and Technology}

Vol. 6, Issue 6, June 2019

[19]. KELLERMANNS, F., EDDLESTON, K., BARNETT, T. \& PEARSON, A. 2008. An exploratory study of family member characteristics and involvement: Effects on entrepreneurial behavior in the family firm. Family Business Review, Vol. 21, No. 1, pp. 399-429.

[20]. KHAN, R., REHMAN, A. \& FATIMA, A. 2009. Transformational leadership and organizational innovation : Moderated by organizational size African Journal of Business management, Vol.3, No1, pp.678-884

[21]. LAGROSEN, S. 2005. Customer involvement in new product development: A relationship marketing perspective European Journal of Innovation Management, Vol. 8, No.4.

[22]. MATHEW, V. 2010. Service delivery through knowledge management in higher education. Journal of Knowledge Management Practice, Vol.11, No.3, pp.1-14.

[23]. NORTHOUSE, P. 2007. Leadership, Theory and practice, California, Sage publication, Inc.

[24]. OBENDHAIN, A. \& JOHNSON, W. 2004. Product and process innovation in service organizations: The influence of organizational culture in higher education insitiutions. The Journal of Applied Management and Entrepreneurship, Vol. 9, No. 3, pp.91-113.

[25]. Phong, L.B., Hui, L. and Son, T.T. (2018) The Mediating Role of Knowledge Sharing in Linking Transformational Leadership and Innovation Capability of SMES: Insights from Vietnam.

[26]. ROGERS, E. 2010. Diffusion of innovation, 4th ed., New York, The Free Press.

[27]. SAENZ, H. 2011. Transformational leadership (pp.299-310) in Bryman, Alan, Collinson, David, Grint, Keith, Jackson, Brad, and Bien, Mary, The SAGE handbook of leadership, London, SAGE Publications Ltd.

[28]. SARRORS, J., C., COOPER, B., K. \& SANTORA, J., C. 2008. Building a climate for innovation through transformational leadership and organizational culture. Journal of Leadership and Organizational Studies, Vol. 15, No. 2, pp.145 - 158.

[29]. SCHILLING, M. A. 2010. Strategic management of technological innovation, 3rd ed., New York McGraw-Hill/Irwin

[30]. SHALLEY, C. E. \& GILSON, L. L. 2004. What leaders need to know: a review of social and contextual factors that can foster or hinder creativity. Leadership Quarterly, Vol. 15, No. 1, pp. 33-54.

[31]. SI, S. S. \& WEI, F. W. 2012. Transformational and transactional leaderships, empowerment climate, and innovation performance: A multilevel analysis in the Chinese context. European Journal of Work and Organisational Psychology, Vol. 21, No.2, pp. 299-320.

[32]. TIDD, J. \& BESSANT, J. 2011. Managing innovation: Integrating, technological , market and organizational change, 4th ed. , London, John Wiley \& Sons Limted.

[33]. TIDD, J., BESSANT, J. \& PAVITT, K. 2005. Managing innovation: Integrating, technological, market and organizational change London, John Wiley \& Sons Limted

[34]. TROTT, P. 2008. Innovation management and new product development, 4th ed., London, Prentic Hall.

[35]. VACCARO, I. G., JANSEN, J. J. P., BOSCH, F. A. J. V. D. \& VOLBERDA, H. W. 2012. Management Innovation and Leadership: The moderating role of organizational size. Journal of Management Studies Vol.49, No.1, pp.28-59.

[36]. YU, H. \& JANTZI, D. 2002. The effects of transformational leadership on teachers' commitment to change in Hong Kong. Jouranal of Educational Administration, Vol. 40, No.3, pp. 368-389.

[37]. Yukl, G. 2010. Leadership in organizations (7th ed.). Upper Saddle River, NJ: Prentice Hall. 